\title{
Dynamics of the woody vegetation of two areas of Cerrado sensu stricto located on different substrates
}

\author{
Letícia Gomes $^{1,5}$, Leandro Maracahipes ${ }^{3}$, Simone Matias Reis ${ }^{4}$, Beatriz Schwantes Marimon ${ }^{2}$, \\ Ben Hur Marimon-Junior ${ }^{2}$ \& Eddie Lenza ${ }^{2}$
}

\begin{abstract}
Differences in substrates can provoke distinct responses in the dynamics of a plant community. We compared changes the floristic, structural and dynamic parameters of the woody vegetation between burned sites dominated by cerrado típico (CT) and cerrado rupestre (CR), which is characterized by the presence of rocky outcrops, over time. We set up 10 plots $(20 \mathrm{~m} \times 50 \mathrm{~m})$ at each site. All individuals (diameter of $\geq 3 \mathrm{~cm}$ at $30 \mathrm{~cm}$ height above the ground) were identified in the two censuses (2009 and 2012) and measured (stem diameter), after an accidental fire in 2008. Changes in floristic parameters between the CT and CR were not significant. However, we found significant differences $(p<0.05)$ in structural and dynamic parameters, such as density $(\mathrm{CT}=1,523$; $\mathrm{CR}=2,171$ ind.ha $\left.^{-1}\right)$, basal area $\left(\mathrm{CT}=8.70 ; \mathrm{CR}=13.00 \mathrm{~m}^{2} \cdot \mathrm{ha}^{-1}\right)$, recruitment rates $(\mathrm{CT}=24.35 ; \mathrm{CR}=15.14 \%$ year $\left.^{-1} ; p=0.01\right)$, gain $\left(\mathrm{CT}=8.58 ; \mathrm{CR}=3.58 \%\right.$ year $\left.^{-1}\right)$, and the loss rates of basal area $(\mathrm{CT}=3.88 ; \mathrm{CR}=2.45 \%$ year $\left.^{-1}\right)$. These differences emphasize the need for a differential evaluation of these sites for the development of effective conservation strategies.
\end{abstract}

Key words: changes, density, floristic, mortality, recruitment.

\section{Resumo}

A diferença de substrato pode causar respostas distintas sobre a dinâmica da comunidade vegetal. O objetivo deste trabalho foi comparar os parâmetros florístico, estruturais e de dinâmica da vegetação entre áreas queimadas de cerrado típico (CT) e cerrado rupestre (CR) (presença de afloramentos rochosos) ao longo do tempo. Foram estabelecidas 10 parcelas $(20 \mathrm{~m} \times 50 \mathrm{~m})$ em cada local. Todos os indivíduos com diâmetro $\geq 3 \mathrm{~cm}$ a $30 \mathrm{~cm}$ de altura acima do solo foram identificados e mediu-se o diâmetro do caule tanto em 2009 quanto em 2012, depois de uma queima acidental em 2008. As mudanças nos parâmetros florísticos não foram significativas entre o CT e CR. Entretanto, foram encontradas diferenças $(p<0,05)$ principalmente com relação aos parâmetros estruturais e de dinâmica, como densidade $\left(\mathrm{CT}=1.523 ; \mathrm{CR}=2.171\right.$ ind.ha $\left.{ }^{-1}\right)$, área basal $\left(\mathrm{CT}=8,70 ; \mathrm{CR}=13,00 \mathrm{~m}^{2} \cdot \mathrm{ha}^{-1}\right)$, taxa de recrutamento $\left(\mathrm{CT}=24,35 ; \mathrm{CR}=15,14 \%\right.$ ano $\left.^{-1} ; p=0,01\right)$, ganho $\left(\mathrm{CT}=8,58 ; \mathrm{CR}=3,58 \%\right.$ ano $\left.^{-1} ; p=0,02\right)$ e perda em área basal $\left(\mathrm{CT}=3,88 ; \mathrm{CR}=2,45 \%\right.$ ano $\left.^{-1}\right)$. Essas diferenças enfatizam a necessidade de avaliar de forma diferenciada essas fisionomias para criação de futuras estratégias de conservação.

Palavras-chave: mudanças, densidade, florística, mortalidade, recrutamento.

\section{Introduction}

The vegetation of the Cerrado biome occurs heterogeneously in space, forming a distinct mosaic (Ribeiro \& Walter 2008). In the classification of Ribeiro \& Walter (2008), the Cerrado sensu stricto is a savanna formation of the Cerrado biome characterized by a sparse tree-shrub stratum with tortuous trunks, irregular branches, and a continuous grassy stratum. It is divided into four physiognomies: cerrado denso (dense cerrado),

\footnotetext{
'Universidade de Brasília, Prog. Pós-graduação em Ecologia, Lab. Ecossistemas, Av. L3 Norte s.n., 70.919-907, Brasília, DF, Brazil.

${ }^{2}$ Universidade do Estado de Mato Grosso, Prog. Pós-graduação em Ecologia e Conservação, Lab. Ecologia Vegetal, Rod. BR 158 s.n., 78.690-000, Nova Xavantina, MT, Brazil.

${ }^{3}$ Universidade Federal de Goiás, Prog. Pós-graduação em Ecologia e Evolução, Lab. Ecologia e Funcionamento de Comunidades, Av. Esperança s.n., 74.001-970, Goiânia, GO, Brazil

${ }^{4}$ Rede BIONORTE UNEMAT/UFAM, Prog. Pós-graduação em Biodiversidade e Biotecnologia, Rod. BR 158 s.n., 78.690-000, Nova Xavantina, MT, Brazil.

${ }^{5}$ Author for correspondence: leticiagomesbio@gmail.com
} 
cerrado típico (typical cerrado), cerrado ralo (sparse cerrado) and cerrado rupestre (rocky cerrado). These physiognomies are distinguished mainly by the type of soil and tree density, height, and cover.

The cerrado rupestre is different from the other three physiognomies because it occurs on soils with rocky outcrops and a reduced content of organic matter, typically on steep and hilly terrain, dominated by litholic neosols (Reatto et al. 2008). By contrast, the cerrado típico is intermediate between the cerrado denso and cerrado ralo, in terms of its tree density (Ribeiro \& Walter 2008), and it is found typically on deep, dystrophic and well-drained latosol type soils, on flat to slightly undulating terrain (Reatto et al. 2008).

The rocky outcrops of the cerrado rupestre act as barriers to the root systems of the woody and shrubby strata, which are forced to grow between the rock crevices and may only increase in density where enough substrate is available (Felfili \& Fagg 2007; Ribeiro \& Walter 2008). However, the presumed physical limitations on the development of cerrado rupestre plants has not been confirmed by the recent studies that have compared the floristic and structural parameters of the woody communities of adjacent cerrado rupestre and cerrado típico communities, indicating that this vegetation is adapted to the conditions prevailing in these environments (Pinto et al. 2009; Gomes et al. 2011). Despite the floristic and structural similarities between cerrado rupestre and cerrado típico sites (Pinto et al. 2009), it is still unclear whether changes in the composition of the vegetation and its structure and dynamics, are similar between these physiognomies over time.

Studies of vegetation dynamics are crucial to the understanding of the intrinsic ecological and temporal processes of plant communities, such as mortality and recruitment (Corrêa \& Van Den Berg 2002; Henriques \& Hay 2002), in particular when these communities have suffered some type of disturbance, such as the fire. In the Cerrado biome, natural or anthropogenic fires are commonly observed during the dry season (Klink \& Machado 2005; Miranda et al. 2010), and the data generated by these studies may contribute to the development of conservation and management strategies (Libano \& Felfili 2006; Pivello 2011). The aim of the present study was to compare changes in the floristic, structural and dynamic parameters of the woody vegetation between burned sites dominated by typical cerrado and rocky cerrado over time (2009-2012).

\section{Material and Methods}

Study area

We conducted this study in the Bacaba

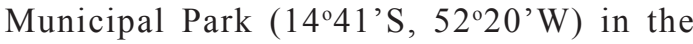
municipality of Nova Xavantina, Mato Grosso, Brazil. The region's climate is of the $A w$ type in Köppen's classification (Peel et al. 2007), with two well-defined seasons: a dry and cool season (April to September) and a hot and rainy season, between October and March (Silva et al. 2008). Mean annual rainfall is $1,520 \mathrm{~mm}$ and average temperature is nearly $24.8^{\circ} \mathrm{C}$ (Marimon-Junior \& Haridasan 2005). The park comprises approximately 500 ha, dominated by cerrado sensu stricto, composed of the cerrado rupestre and cerrado típico physiognomies (Gomes et al. 2011).

We selected two adjacent sites, which had been completely burned by an accidental fire in September 2008. Both sites had previously been protected from fire for over 20 years. As the fire was unplanned, it was not possible to measure vegetation parameters before the event. One site is an area of cerrado típico (CT) located on dystrophic, alic and acidic cambisols (Marimon-Junior \& Haridasan 2005) on flat terrain at altitudes of between $327 \mathrm{~m}$ and $331 \mathrm{~m}$. The second site is an area of cerrado rupestre (CR) established on quartzic lithic neosol (Marimon-Júnior \& Haridasan 2005) on steeplysloping terrain at altitudes ranging from $339 \mathrm{~m}$ to $406 \mathrm{~m}$. We measured the vegetation in January 2009 (four months post-fire) and in January 2012 (40 months post-fire).

\section{Data collection}

We used the permanent plot method of Philip (1994), based on 10 plots of $20 \mathrm{~m} \times 50 \mathrm{~m}$ at each site (CR and CT), with plots being at least $50 \mathrm{~m}$ apart, and a total area of one hectare per site. The $\mathrm{CR}$ plots were arranged perpendicularly to the predominant slope of the outcrop to control for possible variations in the topographic gradient, as suggested by Oliveira-Filho (1994). We measured the stem diameter of all live and dead trees with a diameter $\geq 3 \mathrm{~cm}$ at $30 \mathrm{~cm}$ height above ground level, following Gomes et al. (2014). For taxonomic identification, we compared the botanical material collected in the field with voucher specimens in the collection of the NX Herbarium at Mato Grosso State University in Nova Xavantina. We used the Angiosperm Phylogeny Group's (APG III) (2009) botanical classification system and the taxon names were updated using the "International Plant Names 
Table 1 - Parameters used to compare the post-fire dynamics between the cerrado típico (CT) and cerrado rupestre (CR) in of the Bacaba Municipal Park, Nova Xavantina, Mato Grosso, Brazil. $t=$ time elapsed between surveys; $N_{0}=$ initial number of individuals; $N_{t}=$ final number of individuals; $N_{m}=$ number of dead individuals; $N_{r}=$ number of recruits; $A B=$ initial basal area; $A B=$ final basal area; $A B$ = basal area of dead individuals; $A B=$ basal area of recruits; $A B d=$ decrease in basal area; $A B g={ }^{t}$ increase in basal area; $L n=$ natural logarithm. Adapted with permission from Gomes et al. (2014).

\begin{tabular}{|c|c|c|}
\hline Dynamics parameters & Equation & Author \\
\hline \multicolumn{3}{|l|}{ Number of Individuals $(N)$} \\
\hline Average annual mortality rate $\left(\%\right.$ year $\left.^{-1}\right)$ & $M o=\left\{1-\left[\left(N_{0}-N_{m}\right) / N_{0}\right]^{1 / t}\right\} \times 100$ & Sheil et al. $(1995 ; 2000)$ \\
\hline Average annual recruitment rate $\left(\%\right.$ year $\left.^{-1}\right)$ & $\operatorname{Re}=\left[1-\left(1-N_{r} / N_{t}\right)^{1 / t}\right] \times 100$ & Sheil et al. $(1995 ; 2000)$ \\
\hline Reposition time (turnover) (years) & $\operatorname{Rep}_{N}=\left(\left(T_{1 / 2 N}+T_{2 N}\right) / 2\right)$ & Korning \& Balslev (1994) \\
\hline Half-life time (years) & $T_{1 / 2 N}=\operatorname{Ln}_{(1 / 2)} / \operatorname{Ln}\left(\left[\left(N_{0}-N_{m}\right) / N_{0}\right]^{1 / t}\right)$ & Lieberman et al. (1985) \\
\hline Doubling time (years) & $T_{2 N}=\operatorname{Ln}(2) / \operatorname{Ln}\left(\left[\left(N_{0}+N_{r}\right) / N_{0}\right]^{1 / t}\right)$ & Lieberman et al. (1985) \\
\hline Stability time (years) & $E_{N}=\left(T_{1 / 2 N}-T_{2 N}\right)$ & Korning \& Balslev (1994) \\
\hline Net change rate $\left(\%\right.$ year $\left.^{-1}\right)$ & $C h_{N}=\left[\left(N / N_{0}\right)^{1 / t}-1\right] \times 100$ & Korning \& Balslev (1994) \\
\hline \multicolumn{3}{|l|}{ Basal Area $(A B)$} \\
\hline Average annual loss rate $\left(\%\right.$ year $\left.^{-1}\right)$ & $P e=\left\{1-\left[\left(A B_{0}-A B_{m}-A B_{d}\right) / A B_{0}\right]^{1 / t}\right\} \times 100$ & Guimarães et al. (2008) \\
\hline Average annual rate of gain rate $\left(\%\right.$ year $\left.^{-1}\right)$ & $G=\left\{1-\left[1-\left(\mathrm{AB}_{\mathrm{r}}+\mathrm{AB}_{\mathrm{g}}\right) / \mathrm{AB}_{\mathrm{t}}\right]^{1 / \mathrm{t}}\right\} \times 100$ & Guimarães et al. (2008) \\
\hline Reposition time (turnover) (years) & $\operatorname{Rep}_{A B}=\left(T_{1 / 2 A B}+T_{2 A B}\right) / 2$ & Korning \& Balslev (1994) \\
\hline Half-life time (years) & $T_{1 / 2 A B}=\operatorname{Ln}(1 / 2)=\operatorname{Ln}\left(\left[\left(A B_{0}-A B_{m} / A B_{0}\right)\right]^{1 / t}\right)$ & Lieberman et al. (1985) \\
\hline Doubling time (years) & $T_{2 A B}=\operatorname{Ln}(2) \operatorname{Ln}\left(\left[\left(A B_{0}+A B_{r}\right) / A B_{0}\right]^{1 / t}\right)$ & Lieberman et al. (1985) \\
\hline Stability time (years) & $E_{A B}=\left(T_{1 / 2 A B}-T_{2 A B}\right)$ & Korning \& Balslev (1994) \\
\hline Net change rate $\left(\%\right.$ year $\left.^{-1}\right)$ & $C h_{A B}=\left[\left(A B_{t} / A B_{0}\right)^{1 / t}-1\right] \times 100$ & Korning \& Balslev (1994) \\
\hline
\end{tabular}

Index-2012" (<http://www.ipni.org $>$ ). The fertile botanical material collected in the field was deposited at the NX Herbarium.

\section{Floristic parameters}

Species richness at each site (CT and CR) in both censuses (2009 and 2012) was estimated using the matrix of the density of individuals per plot through a Detrended Correspondence Analysis (DCA), which spatializes the species data according to the abundance of species, in order to best visualize the groupings (Kent \& Coker 1992; McCune \& Grace 2002).

\section{Structural parameters}

We calculated the density (number of individuals per hectare) and basal area (volume of stems per hectare) of individuals at both sites using the Mata Nativa 2.0 software (Cientec 2006). The $t$ test for independent samples was used to compare the density and basal area between sites in each census, and the paired $t$ test was used to compare density and basal area between censuses at each site (Zar 2010).

\section{Dynamic parameters}

For each census, we calculated the dynamic parameters of the vegetation, related to the number of individuals and their basal area (Tab. 1), including the mean annual mortality rate (annual percentage of dead individuals) and recruitment rate (annual percentage of individuals who have reached minimum inclusion diameter, i.e., $\geq$ $3 \mathrm{~cm}$ at $30 \mathrm{~cm}$ height above ground level), the replacement time or turnover rate (number of years needed to reestablish the number of individuals or basal area initial), half-life (the number of years needed for a community to reduce by $50 \%$ the number of individuals or the basal area), and doubling time (the amount of years it takes to double the number of individuals or basal area of a community), stability time (number of years needed to stabilize the number of individuals or basal area), and the net rate of change (annual 
percentage change in number of individuals or basal area).

In order to correct the bias related to the variation in the interval between censuses, we applied a correction factor (Lewis et al. 2004), based on the formula $\lambda_{\text {corr }}=\lambda \times t^{0.08}$, where: $\lambda$ is the rate and $t$ is the interval in years. We also calculated the number of individuals of each diameter class that persisted, died, were recruited and either immigrated or emigrated (Lieberman et al. 1985), as proposed by Spiegel (1976). We applied the $t$ test for independent samples to compare these parameters between sites (Hollander \& Wolfe 1973). For each site, we tested the association between diameter classes and annual rates of mortality and recruitment, and loss and gain (basal area) using Spearman's correlation, $\mathrm{R}_{s}$ (Zar 2010).

All these analyses were run in the appropriate package of the $\mathrm{R}$ statistical software (R Development Core Team 2009), considering a $5 \%$ level of significance. Homogeneity of variances was assessed by Levene's test, and the data were log-transformed when homoscedasticity was not found (Zar 2010).

\section{Results}

Floristic parameters

The CT plots were well separated from the CR plots in the ordination analysis (DCA) (Fig. 1). Species richness in the CT increased 7.3\% from 89 to 96 between the 2009 and 2012 censuses. In the $\mathrm{CR}$, during the same period, species richness increased $2.5 \%$ from 78 to 80 (Tabs. 2; 3).

\section{Structural parameters}

In 2009, the CR presented 648 ind.ha ${ }^{-1}$ more than $\mathrm{CT}$, although densities were similar at the two sites in 2012. The density of individuals in the CT varied between censuses (2009 and 2012), increasing by $46.1 \%$ (Tabs. 2; 3). Density in the CR also increased between censuses (2009 and 2012 ), by $26.8 \%$. Basal area was greater in the CR in both years (Tab. 2), with an excess of 4.30 $\mathrm{m}^{2}$.ha $\mathrm{a}^{-1}$ being recorded in 2009 , and $3.65 \mathrm{~m}^{2}$. ha $\mathrm{a}^{-1}$ in 2012 in comparison with the CT. Total basal area at each site (CT and CR) also varied between censuses (2009 and 2012), with basal area increasing by $24.5 \%\left(2.82 \mathrm{~m}^{2}\right.$.ha $\left.\mathrm{ha}^{-1}\right)$ in the CT and by $14.3 \%$ (2.17 $\mathrm{m}^{2}$.ha-1) in the CR (Tabs. 2; 3). Density increased at both sites owing to the fact that the density of some species more than doubled between censuses. These species were Kielmeyera rubriflora in the CR and CT and Erythroxylum suberosum, Heteropterys byrsonimifolia and Myrcia lanuginosa in the CT. Furthermore, increases in density and basal area occurred in smaller diameter classes in both the CT (Figs. 2c,d) and CR (Figs. 3c,d).

\section{Dynamic parameters}

There was no difference between sites in mean annual mortality rates, although the annual recruitment rate was higher in the $\mathrm{CT}$ in comparison with the CR. Mean annual recruitment was higher than mortality, resulting in an increase in the density of individuals at both sites over the course of the study period (Tabs. 2; 4). The mean annual rate of loss of basal area was lower than that of the gain in basal area at both sites, although rates of basal area loss and gain were both greater in the CT compared with the CR.

Half-life times were higher than the doubling times (individuals and basal area) recorded at both sites, and the doubling time was higher in the CR than in the CT in both cases. Even so, half-life and stability times were similar at both sites, not only in terms of the number of individuals but also basal area (Tab. 4). In addition, the net rates of change in the number of individuals and basal area were positive at both sites, while only the basal area turnover rates were lower in the CT compared to the CR (Tab. 4).

Higher mortality rates were recorded in the smaller diameter classes in both the $\mathrm{CT}$ and $\mathrm{CR}$

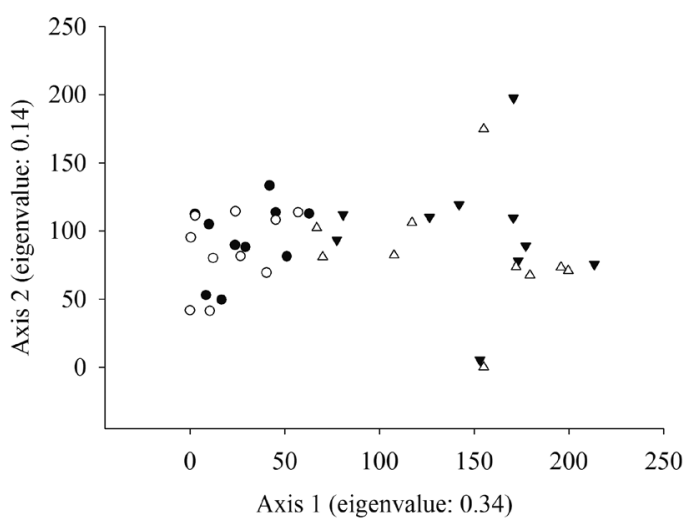

Figure 1 - Arrangement of the DCA (Detrended Correspondence Analysis) ordination axes of the woody vegetation plots sampled in the cerrado típico in 2009 $(\boldsymbol{\nabla})$ and $2012(\Delta)$ and the cerrado rupestre in 2009 (•) and 2012 (०) in Bacaba Municipal Park, Nova Xavantina, Mato Grosso, Brazil. 
Table 2 - Families, species, and density of woody individuals recorded in the cerrado típico (CT) and cerrado rupestre (CR) in Bacaba Municipal Park, Nova Xavantina, Mato Grosso, Brazil. The species are ordered by the density found in the CR in $2009 . *$ = species that increased by at least $50 \%$ between censuses in the number of individuals.

\begin{tabular}{|c|c|c|c|c|c|}
\hline \multirow{2}{*}{ Species } & \multirow{2}{*}{ Family } & \multicolumn{2}{|c|}{ CT } & \multicolumn{2}{|c|}{$\mathbf{C R}$} \\
\hline & & 2009 & 2012 & 2009 & 2012 \\
\hline Qualea parviflora Mart. & Vochysiaceae & 220 & 298 & 275 & 313 \\
\hline Erythroxylum suberosum A.St.-Hil. & Erythroxylaceae & 60 & $150^{*}$ & 240 & 270 \\
\hline Kielmeyera rubriflora Cambess. & Clusiaceae & 45 & $121 *$ & 148 & $403 *$ \\
\hline Vatairea macrocarpa (Benth.) Ducke & Fabaceae & 15 & 36 & 126 & 231 \\
\hline Anacardium occidentale L. & Anacardiaceae & 37 & 47 & 91 & 97 \\
\hline Heteropterys byrsonimifolia A.Juss. & Malpighiaceae & 24 & $105^{*}$ & 84 & 141 \\
\hline Eugenia aurata O.Berg & Myrtaceae & 30 & 30 & 77 & 75 \\
\hline Syagrus flexuosa (Mart.) Becc. & Arecaceae & 69 & 137 & 76 & 95 \\
\hline Pseudobombax longiflorum (Mart. \& Zucc.) A.Robyns & Malvaceae & 24 & 45 & 75 & 148 \\
\hline Dalbergia miscolobium Benth. & Fabaceae & 2 & 4 & 59 & 87 \\
\hline Tachigali aurea Tul. & Fabaceae & 22 & 31 & 59 & 63 \\
\hline Davilla elliptica A.St.-Hil. & Dilleniaceae & 127 & 145 & 56 & 51 \\
\hline Lafoensia pacari A.St.-Hil. & Lythraceae & 13 & 75 & 45 & 66 \\
\hline Dipteryx alata Vogel & Fabaceae & 15 & 30 & 44 & 50 \\
\hline Leptolobium dasycarpum Vogel & Fabaceae & 4 & 7 & 41 & 43 \\
\hline Qualea multiflora Mart. & Vochysiaceae & 26 & 39 & 41 & 55 \\
\hline Hymenaea stigonocarpa Mart. ex Hayne & Fabaceae & 8 & 13 & 40 & 55 \\
\hline Myrcia lanuginosa O.Berg & Myrtaceae & 94 & $327^{*}$ & 36 & 62 \\
\hline Magonia pubescens A.St.-Hil. & Sapindaceae & 8 & 11 & 35 & 33 \\
\hline Erythroxylum tortuosum Mart. & Erythroxylaceae & 12 & 16 & 32 & 45 \\
\hline Aspidosperma macrocarpon Mart. & Apocynaceae & 2 & 2 & 29 & 25 \\
\hline Pterodon pubescens (Benth.) Benth. & Fabaceae & 1 & 2 & 28 & 38 \\
\hline Aspidosperma tomentosum Mart. & Apocynaceae & 61 & 70 & 27 & 25 \\
\hline Arrabidaea cinnamomea (A. DC.) Sandwith & Bignoniaceae & - & - & 24 & 27 \\
\hline Vellozia squamata Pohl & Velloziaceae & 4 & 4 & 22 & 31 \\
\hline Tocoyena formosa (Cham. \& Schltdl.) K.Schum. & Rubiaceae & 10 & 23 & 21 & 28 \\
\hline Mezilaurus crassiramea (Meisn.) Taub. ex Mez & Lauraceae & 1 & 1 & 18 & 17 \\
\hline Byrsonima coccolobifolia Kunth & Malpighiaceae & 42 & 51 & 17 & 15 \\
\hline Plathymenia reticulata Benth. & Fabaceae & 6 & 10 & 17 & 26 \\
\hline Eriotheca gracilipes (K.Schum.) A.Robyns & Malvaceae & 17 & 41 & 16 & 22 \\
\hline Qualea grandiflora Mart. & Vochysiaceae & 22 & 27 & 16 & 21 \\
\hline Byrsonima pachyphylla A.Juss. & Malpighiaceae & 81 & 106 & 15 & 14 \\
\hline Cordiera sessilis (Vell.) Kuntze & Rubiaceae & - & - & 15 & 16 \\
\hline Guapira graciliflora (Mart. ex Schmidt) Lundell & Nyctaginaceae & 3 & 12 & 15 & 13 \\
\hline Agonandra brasiliensis Miers ex Benth. \& Hook.f. & Opiliaceae & 1 & 3 & 14 & 16 \\
\hline
\end{tabular}




\begin{tabular}{|c|c|c|c|c|c|}
\hline \multirow{2}{*}{ Species } & \multirow{2}{*}{ Family } & \multicolumn{2}{|c|}{ CT } & \multicolumn{2}{|c|}{$\mathbf{C R}$} \\
\hline & & 2009 & 2012 & 2009 & 2012 \\
\hline Ouratea spectabilis (Mart.) Engl. & Ochnaceae & 24 & 42 & 13 & 9 \\
\hline Bowdichia virgilioides Kunth & Fabaceae & 7 & 10 & 12 & 11 \\
\hline Kielmeyera coriacea Mart. \& Zucc. & Clusiaceae & 6 & 9 & 12 & 21 \\
\hline Tabebuia aurea (Silva Manso) Benth. \& Hook.f. ex S.Moore & Bignoniaceae & 10 & 13 & 12 & 12 \\
\hline Mouriri elliptica Mart. & Melastomataceae & 13 & 15 & 11 & 10 \\
\hline Salvertia convallariodora A.St.-Hil. & Vochysiaceae & 41 & 46 & 9 & 10 \\
\hline Eugenia glazioviana Kiaersk. & Myrtaceae & - & - & 8 & 7 \\
\hline Andira cujabensis Benth. & Fabaceae & 3 & 5 & 7 & 7 \\
\hline Astronium fraxinifolium Schott & Anacardiaceae & 12 & 30 & 7 & 8 \\
\hline Eugenia gemmiflora O.Berg & Myrtaceae & 3 & 3 & 6 & 9 \\
\hline Jacaranda brasiliana (Lam.) Pers. & Bignoniaceae & - & - & 6 & 6 \\
\hline Mimosa laticifera Rizzini \& A.Mattos & Fabaceae & 11 & 44 & 6 & 13 \\
\hline Neea theifera Oerst. & Nyctaginaceae & - & - & 6 & 6 \\
\hline Pouteria gardneri (Mart. \& Miq.) Baehni & Sapotaceae & - & - & 6 & 6 \\
\hline Curatella americana $\mathrm{L}$. & Dilleniaceae & 35 & 33 & 5 & 5 \\
\hline Luetzelburgia praecox (Harms) Harms & Fabaceae & 7 & 7 & 5 & 5 \\
\hline Rourea induta Planch. & Connaraceae & 1 & 7 & 5 & 7 \\
\hline Syagrus comosa (Mart.) Mart. & Arecaceae & 8 & 49 & 5 & 20 \\
\hline Diplopterys pubipetala (A. Juss.) W.R. Anderson \& C. Davis & Malpighiaceae & 2 & 4 & 4 & 5 \\
\hline Connarus suberosus Planch. & Connaraceae & 6 & 17 & 4 & 4 \\
\hline Erythroxylum engleri O.E.Schulz & Erythroxylaceae & 4 & 14 & 4 & 5 \\
\hline Himatanthus obovatus (Müll.Arg.) Woodson & Apocynaceae & - & 34 & 4 & 11 \\
\hline Myrcia tomentosa (Aubl.) DC. & Myrtaceae & - & - & 4 & 3 \\
\hline Pouteria ramiflora (Mart.) Radlk. & Sapotaceae & 23 & 32 & 4 & 4 \\
\hline Annona coriacea Mart. & Annonaceae & 13 & 25 & 3 & 5 \\
\hline Antonia ovata Pohl & Loganiaceae & - & 5 & 3 & 3 \\
\hline Buchenavia tomentosa Eichler & Combretaceae & - & - & 3 & 3 \\
\hline Ouratea hexasperma (A.St.-Hil.) Baill. & Ochnaceae & 40 & 50 & 3 & 4 \\
\hline Cordiera elliptica (Cham.) Kuntze & Rubiaceae & - & - & 2 & 1 \\
\hline Cybistax antisyphilitica (Mart.) Mart. & Bignoniaceae & 2 & 2 & 2 & 2 \\
\hline Emmotum nitens (Benth.) Miers & Emmotaceae & 2 & 6 & 2 & 2 \\
\hline Heisteria ovata Benth. & Olacaceae & 1 & 1 & 2 & 2 \\
\hline Protium heptaphyllum (Aubl.) Marchand & Burseraceae & 1 & 7 & 2 & 2 \\
\hline Brosimum gaudichaudii Trécul & Moraceae & 6 & 20 & 1 & 1 \\
\hline Casearia sylvestris Sw. & Salicaceae & 2 & 4 & 1 & 3 \\
\hline Copaifera langsdorffii Desf. & Fabaceae & - & - & 1 & 1 \\
\hline Dimorphandra mollis Benth. & Fabaceae & 2 & 17 & 1 & 6 \\
\hline
\end{tabular}




\begin{tabular}{|c|c|c|c|c|c|}
\hline \multirow{2}{*}{ Species } & \multirow{2}{*}{ Family } & \multicolumn{2}{|c|}{ CT } & \multicolumn{2}{|c|}{$\mathbf{C R}$} \\
\hline & & 2009 & 2012 & 2009 & 2012 \\
\hline Erythroxylum testaceum Peyr. & Erythroxylaceae & 11 & 12 & 1 & 1 \\
\hline Ferdinandusa elliptica (Pohl) Pohl & Rubiaceae & - & - & 1 & 1 \\
\hline Hancornia speciosa Gomes & Apocynaceae & - & 1 & 1 & 2 \\
\hline Peritassa campestris (Cambess.) A.C.Sm. & Celastraceae & - & 1 & 1 & - \\
\hline Plenckia populnea Reissek & Celastraceae & 7 & 10 & 1 & 2 \\
\hline Strychnos pseudoquina A.St.-Hil. & Loganiaceae & 5 & 5 & 1 & 1 \\
\hline Aspidosperma multiflorum A.DC. & Apocynaceae & 1 & 2 & - & - \\
\hline Callisthene fasciculata Mart. & Vochysiaceae & 6 & 10 & - & - \\
\hline Caryocar brasiliense Cambess. & Caryocaraceae & 3 & 9 & - & - \\
\hline Couepia grandiflora (Mart. \& Zucc.) Benth. & Chrysobalanaceae & 27 & 41 & - & 1 \\
\hline Diospyros hispida A.DC. & Ebenaceae & 2 & 38 & - & - \\
\hline Enterolobium gummiferum (Mart.) J.F.Macbr. & Fabaceae & - & 1 & - & - \\
\hline Eremanthus brasiliensis (Gardner) MacLeish & Asteraceae & 1 & - & - & - \\
\hline Erythroxylum daphnites Mart. & Erythroxylaceae & 1 & 1 & - & - \\
\hline Eugenia punicifolia (Kunth) DC. & Myrtaceae & 2 & 2 & - & - \\
\hline Eugenia sp. & Myrtaceae & 1 & 1 & - & - \\
\hline Euplassa inaequalis (Pohl) Engl. & Proteaceae & - & 2 & - & - \\
\hline Guapira noxia (Netto) Lundell & Nyctaginaceae & 2 & 2 & - & - \\
\hline Handroanthus ochraceus (Cham.) Mattos & Bignoniaceae & 2 & 4 & - & - \\
\hline Licania humilis Cham. \& Schltdl. & Chrysobalanaceae & 14 & 20 & - & - \\
\hline Luehea sp. & Malvaceae & - & 1 & - & - \\
\hline Machaerium acutifolium Vogel & Fabaceae & 1 & 14 & - & 1 \\
\hline Myrcia camapuanensis N.Silveira & Myrtaceae & 6 & 5 & - & - \\
\hline Myrcia multiflora (Lam.) DC. & Myrtaceae & 13 & 13 & - & - \\
\hline Myrcia splendens (Sw.) DC. & Myrtaceae & 4 & 3 & - & - \\
\hline Peltogyne confertiflora (Mart. ex Hayne) Benth. & Fabaceae & 1 & 1 & - & - \\
\hline Pseudobombax tomentosum (Mart. \& Zucc.) A.Robyns & Malvaceae & 3 & 3 & - & - \\
\hline Psidium sp. & Myrtaceae & 1 & 5 & - & - \\
\hline Roupala montana Aubl. & Proteaceae & 5 & 16 & - & - \\
\hline Salacia crassifolia (Mart. ex Schult.) G.Don & Celastraceae & 1 & 4 & - & - \\
\hline Salacia elliptica (Mart. ex Schult.) G.Don & Celastraceae & 1 & 2 & - & - \\
\hline Simarouba versicolor A.St.-Hil. & Simaroubaceae & 5 & 9 & - & 1 \\
\hline Stryphnodendron obovatum Benth. & Fabaceae & 1 & 4 & - & - \\
\hline Terminalia argentea Mart. & Combretaceae & 2 & 9 & - & - \\
\hline Vochysia rufa Mart. & Vochysiaceae & 3 & 5 & - & - \\
\hline Xylopia aromatica (Lam.) Mart. & Annonaceae & - & 1 & - & - \\
\hline Total & & 1,523 & 2,827 & 2,171 & 2,966 \\
\hline
\end{tabular}


Table 3 - Comparison of structural parameters and species composition of the woody vegetation recorded in the cerrado típico (CT) and cerrado rupestre (CR) in Bacaba Municipal Park, Nova Xavantina, Mato Grosso, Brazil. $t_{\text {par }}=$ paired $t$ test; $t=t$ test; and $*=$ significant difference $(p \leq 0.05)$.

\begin{tabular}{|c|c|c|c|c|}
\hline Parameters & СТ 2009 & CT 2012 & CR 2009 & CR 2012 \\
\hline Richness & 89 & 96 & 78 & 81 \\
\hline Density & 1,523 & 2,827 & 2,171 & 2,966 \\
\hline \multirow[t]{3}{*}{ Basal area } & 8.70 & 11.52 & 13.00 & 15.17 \\
\hline & 2009 & 2012 & CR & CT \\
\hline & $\mathrm{CR} \times \mathrm{CT}$ & $\mathrm{CR} \times \mathrm{CT}$ & $2009 \times 2012$ & $2009 \times 2012$ \\
\hline Density & $t=2.84 ; p=0.001^{*}$ & $t=0.75 ; p=0.46$ & $t_{\mathrm{par}}=-5.54 ; p<0.001 *$ & $t_{\mathrm{par}}=-9.11 ; p<0.001 *$ \\
\hline Basal area & $t=4.42 ; p<0.001^{*}$ & $t=3.98 ; p<0.001^{*}$ & $t_{\mathrm{par}}=-11.27 ; p<0.001^{*}$ & $t_{\mathrm{par}}=-10.19 ; p<0.001^{*}$ \\
\hline
\end{tabular}

(Figs. 2a; 3a). Higher mean annual recruitment rates and greater gains in basal area were also recorded in the smaller diameter classes at both sites (Figs. 2b; 3b). Negative correlations were obtained at both sites between diameter classes and mortality, recruitment, and loss and gain rates (Tab. 4). In addition, most of the diameter classes (except $21-24 \mathrm{~cm}$ ) presented positive net rates of change at both sites. The $21-24 \mathrm{~cm}$ class lost more individuals than it recruited, however (Figs. 2c,d; 3c,d).

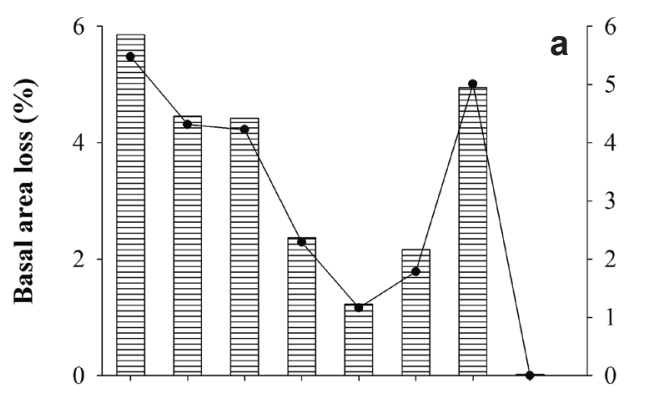

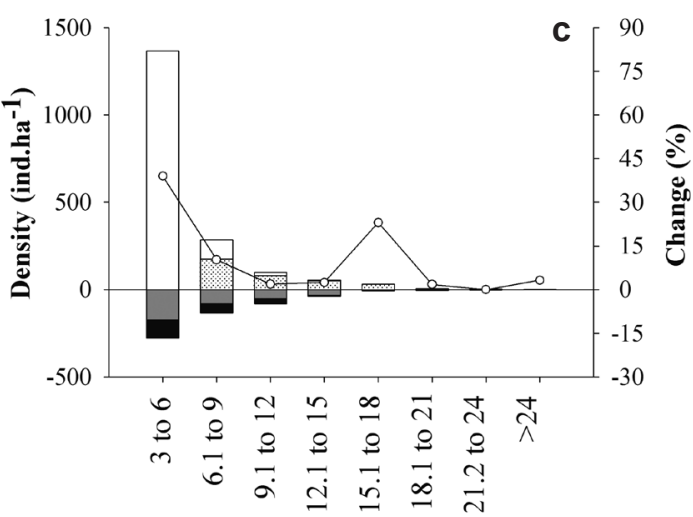

Diameter class $(\mathbf{c m})$
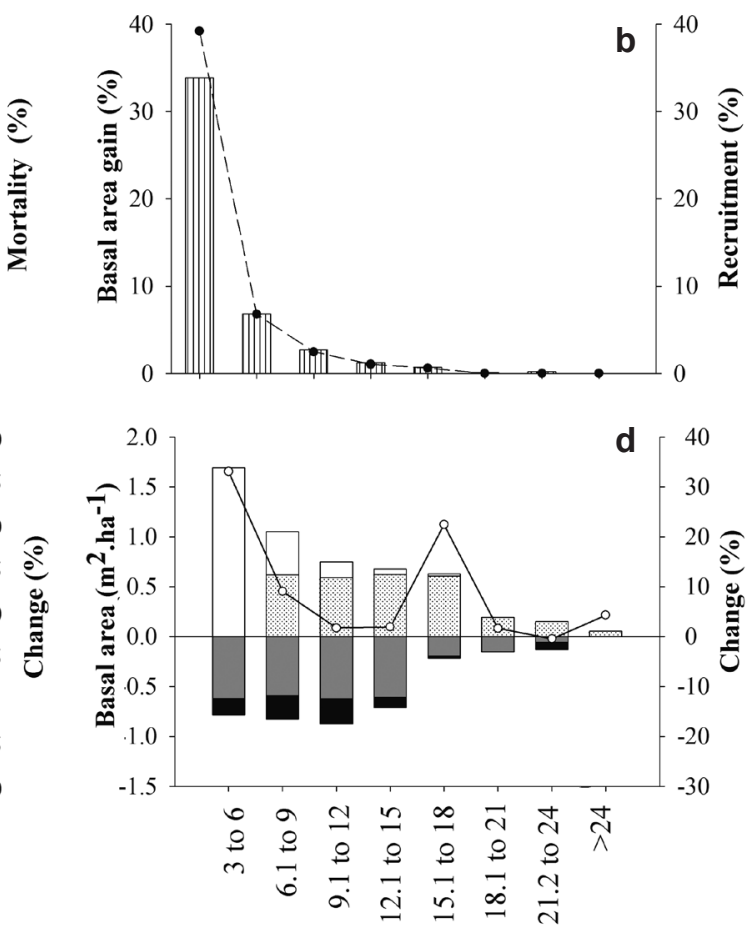

Diameter class (cm)

Figure 2 - Structural parameters and dynamics of the woody vegetation in 2009 and 2012 in the cerrado típico of the Bacaba Municipal Park, Nova Xavantina, Mato Grosso, Brazil - a. average annual rate of loss of basal area (horizontal stripes) and mean annual individual mortality rate (-๑-); b. average annual rate of gain in basal area (vertical stripes) and mean annual recruitment rate of individuals (-- --); c. dynamic parameters in density; d. dynamic parameters in basal area $(\square=$ egress; $\boldsymbol{\square}=$ dead; ; $=$ ingress; $\square=$ recruit; $-\circ-=$ change $)$. 
Table 4 - Structural parameters and dynamic of the woody vegetation in the cerrado típico (CT) and cerrado rupestre (CR) in Bacaba Municipal Park, Nova Xavantina, Mato Grosso, Brazil. $t=t$ test; $\mathrm{R}=$ Spearman's correlation; * = significant difference; and $* *=$ significant correlation $(p \leq 0.05)$.

\begin{tabular}{|c|c|c|c|c|c|}
\hline \multirow[b]{2}{*}{ Dynamics parameters } & \multirow[b]{2}{*}{ CT } & \multirow[b]{2}{*}{$\mathbf{C R}$} & \multirow[b]{2}{*}{ Test } & \multicolumn{2}{|c|}{ Correlation } \\
\hline & & & & CT & CR \\
\hline \multicolumn{6}{|l|}{ Number of individuals } \\
\hline $\begin{array}{l}\text { Average annual mortality rate } \\
\left(\% \text { year }^{-1}\right)\end{array}$ & 4.92 & 6.20 & $t=0.75 ; p=0.46$ & $\mathrm{R}_{s}=-1.0 ; p=0.02 * *$ & $\mathrm{R}_{s}=-0.78 ; p=0.05-* *$ \\
\hline $\begin{array}{l}\text { Average annual recruitment rate } \\
\left(\% \text { year }^{-1}\right)\end{array}$ & 24.35 & 15.40 & $t=-2.85 ; p=0.01^{*}$ & $\mathrm{R}_{s}=-1.0 ; p=0.02 * *$ & $\mathrm{R}_{s}=-1.0 ; p=0.02 * *$ \\
\hline $\begin{array}{l}\text { Reposition time (turnover) } \\
\text { (years) }\end{array}$ & 9.85 & 10.69 & $t=0.54 ; p=0.59$ & - & - \\
\hline Half-life time (years) & 16.39 & 15.78 & $t=-0.60 ; p=0.55$ & - & - \\
\hline Doubling time (years) & 3.31 & 5.60 & $t=2.85 ; p=0.01^{*}$ & - & - \\
\hline Stability time (years) & 13.08 & 10.18 & $t=-2.05 ; p=0.06$ & - & - \\
\hline Net change rate $\left(\%\right.$ year $\left.^{-1}\right)$ & 25.00 & 11.97 & $t=-3.08 ; p=0.01^{*}$ & - & - \\
\hline \multicolumn{6}{|l|}{ Basal area } \\
\hline $\begin{array}{l}\text { Average annual loss rate } \\
(\% \text { year-1 })\end{array}$ & 3.88 & 2.45 & $t=-2.60 ; p=0.02^{*}$ & $\mathrm{R}_{s}=-0.98 ; p<0.01^{* *}$ & $\mathrm{R}_{s}=-0.86 ; p=0.01^{* *}$ \\
\hline $\begin{array}{l}\text { Average annual of gain rate } \\
(\% \text { year-1) }\end{array}$ & 8.58 & 3.58 & $t=-4.33 ; p<0.01^{*}$ & $\mathrm{R}_{s}=-0.98 ; p<0.01 * *$ & $\mathrm{R}_{s}=-1 ; p<0.01 * *$ \\
\hline $\begin{array}{l}\text { Reposition time (turnover) } \\
\text { (years) }\end{array}$ & 15.72 & 28.24 & $t=3.44 ; p<0.01 *$ & - & - \\
\hline Half-life time (years) & 21.98 & 34.92 & $t=2.13 ; p=0.05$ & - & - \\
\hline Doubling time (years) & 9.48 & 21.56 & $t=4.34 ; p<0.01^{*}$ & - & - \\
\hline Stability time (years) & 12.50 & 13.36 & $t=-0.14 ; p=0.89$ & - & - \\
\hline Net change rate $\left(\%\right.$ year $\left.^{-1}\right)$ & 19.56 & 5.77 & $t=-3.01 ; p=0.01 *$ & - & - \\
\hline
\end{tabular}

\section{Discussion}

Changes in species richness were small and similar between CR and CT. Overall changes in species richness in the Cerrado biome tend to be small and transitory (Felfili et al. 2000; Aquino et al. 2007), even in areas that have suffered some kind of disturbance, such as natural fire (Gomes et al. 2014; Lopes et al. 2009). In addition, these small changes were due to species that occur at low densities, where the death or recruitment of a small number of individuals may easily provoke a decrease or increase in species richness. While the
CT and CR were similar floristically, the two sites were classified separately, indicating the existence of preferential groups of species between sites (Gomes et al. 2011).

The greater increase in density and recruitment rates in the CT was reflected in shorter doubling times at this site. In other words, the number of individuals in the CT doubles over a shorter period than in the CR. The similar mortality rates between the CR and CT were reflected in similar half-life times, that is, both sites are reducing in number of individuals within similar periods. In addition, the higher mortality, recruitment, and loss and gain 
rates observed in the $\mathrm{CT}$ made this community more dynamic in comparison with the CR (Oliveira-Filho et al. 1997).

While it was not possible to determine these parameters before the fire (2008), the density and basal area accumulated between censuses (2009 and 2012) indicate that the vegetation at both sites was restructured, with a higher increase in density and basal area being recorded in the $\mathrm{CT}$ in comparison with the CR. The higher values recorded in the CT were supported primarily by Erythroxylum suberosum, Kielmeyera rubriflora, Heteropterys byrsonimifolia and Myrcia lanuginosa, which occurred at both sites, but increased in density by $50 \%$ or more, only in the CT.

The dynamic parameters, although varying between sites, indicate that both communities are recovering from the fire, based on their higher recruitment than mortality, as well as higher ratios of gain to loss and half-life to doubling times. The positive rates of change found in the present study confirm the recovery of the study communities, as observed by Corrêa \& Van Den Berg (2002). Positive patterns of change are usually reported from areas which have not suffered recent disturbance (Henriques \& Hay 2002; Mews et al. 2011), thus indicating that both the CR and the $\mathrm{CT}$ are able to recover from fire damage in approximately three years.

The similar levels of stability found at the two sites (CT and $\mathrm{CR}$ ) indicate that they require a similar interval of time to recuperate density and basal area, as suggested by Korning \& Balslev (1994). Mews et al. (2011) also reported longer stability times (years) (number of individuals $=47.01$, basal area $\left.=67.52 \mathrm{~m}^{2} \cdot \mathrm{ha}^{-1}\right)$ in a nearby area of cerrado sensu stricto protected from fire, although in this study, a minimum basal diameter of $5 \mathrm{~cm}$ was used.
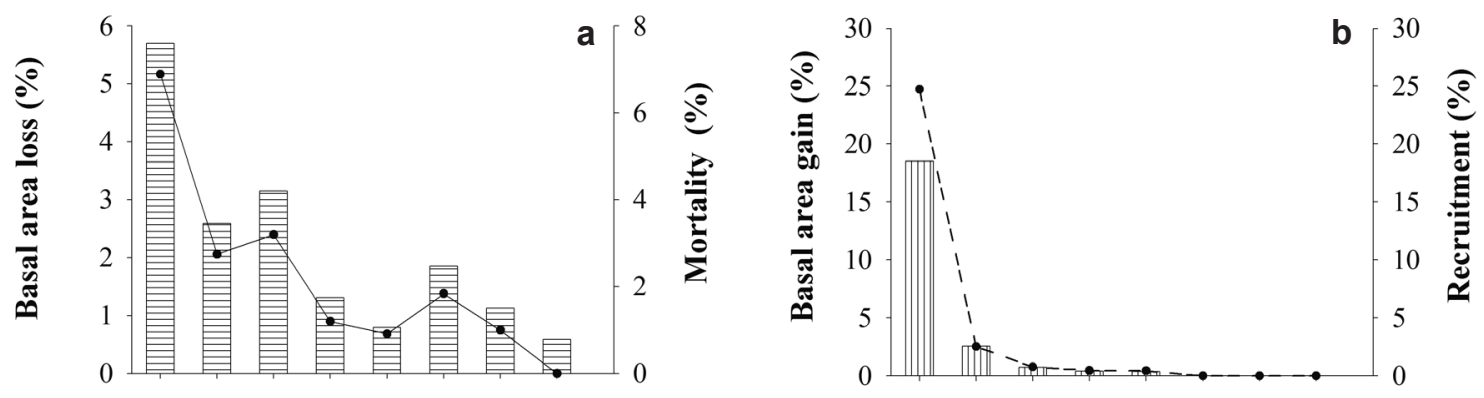

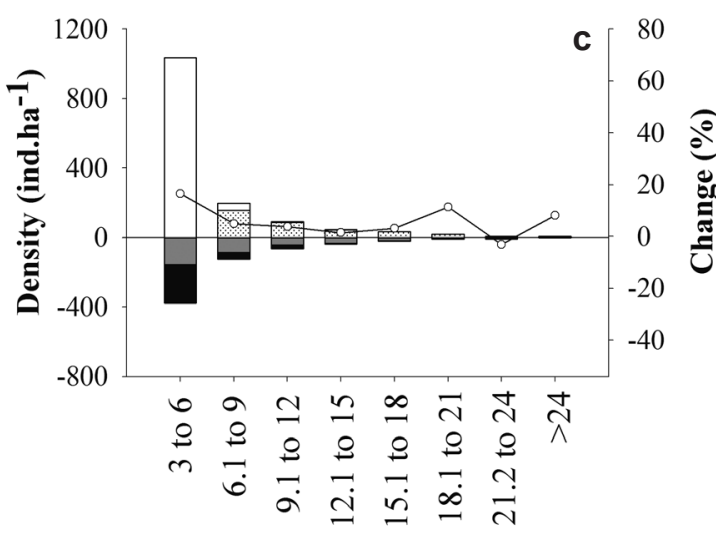

Diameter class (cm)

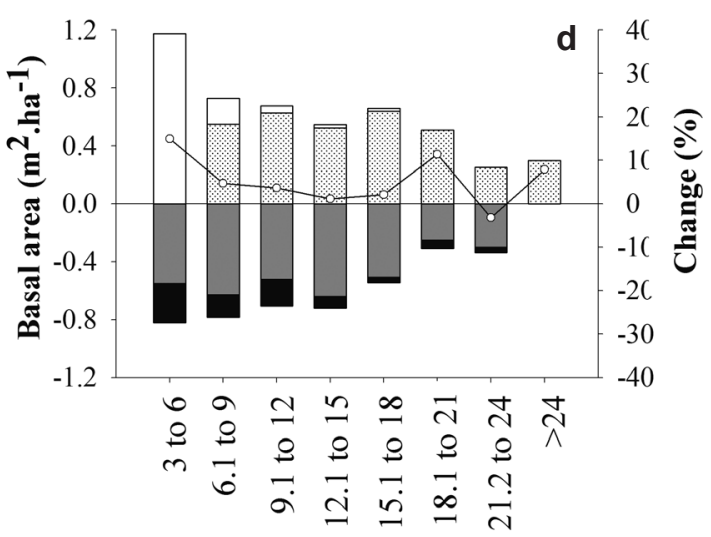

Diameter class $(\mathrm{cm})$

Figure 3 - Structural parameters and dynamics of the woody vegetation in 2009 and 2012 in the cerrado rupestre of the Bacaba Municipal Park, Nova Xavantina, Mato Grosso, Brazil. a. average annual rate of loss of basal area (horizontal stripes) and mean annual mortality rate of individuals (-๑-); b. average annual rate of gain in basal area (vertical stripes) and mean annual recruitment rate of individuals (--•--); c. dynamic parameters in density; d. dynamic parameters in basal area $(\square=$ egress; $\square=$ dead; ; $=$ ingress; $\square=$ recruit; $-\circ-=$ change $)$. 
The negative correlations between diameter classes and both mortality rates and the reduction in basal area recorded at both sites indicate a greater susceptibility of smaller individuals, possibly due to occurrence of fire at these sites in 2008. Smaller individuals appear to be more affected by fire because they have thinner bark, less well developed underground reserve organs, and are more exposed to the flames (Miranda \& Sato 2005; Miranda et al. 2010). Even so, the higher mortality and loss rates recorded in the smaller diameter classes were balanced by the elevated rates of recruitment and gain recorded in these classes, with higher values being recorded in the $\mathrm{CT}$ in comparison with the CR.

The differences between the structural (density and basal area) and dynamic (recruitment rate, loss and gain rate, reposition time, doubling time and net change rate) parameters suggest that the difference in substrate between the CT and CT may underpin distinct responses in the dynamics of vegetation. These differences emphasize the need to evaluate these physiognomies separately for the development of future conservation strategies.

\section{Acknowledgments}

The authors thank the Brazilian National Council for Scientific and Technological Development (CNPq) and PELD (Project on the Cerrado-Amazon Forest Transition, ecological and socio-environmental bases for conservation, process no. 558069/2009-6) and PROCAD UnB/ UNEMAT (National Program for Academic Cooperation, University of Brasília and Mato Grosso State University. Process n. 109/2007) projects, as well as the Coordination of Higher Education Training (CAPES) for logistic and financial support.

\section{References}

Aquino, F.G.; Walter, B.M.T. \& Ribeiro, J.F. 2007. Woody community dynamics in two fragments of "cerrado" stricto sensu over a seven-year period (1995-2002), MA, Brazil. Revista Brasileira de Botanica 30: 113-121.

APG III - Angiosperm Phylogeny Group. 2009. An update of the Angiosperm Phylogeny Group classification for the orders and families of flowering plants: APG III. Botanical Journal of the Linnean Society 161: 105-121.

Cientec - Consultoria e desenvolvimento de sistemas. 2006. Mata nativa 2. Manual do usuário, Viçosa. 295 .
Corrêa, B.S. \& Van Den Berg, E. 2002. Estudo da dinâmica da população de Xylopia brasiliensis Sprengel em relação a parâmetros populacionais e da comunidade em uma floresta de galeria em Itutinga, MG, Brasil. Cerne 8: 01-12.

Felfili, J.M. \& Fagg, C.W. 2007. Floristic composition, diversity and structure of the "cerrado" sensu strict on rocky soils in northern Goiás and southern Tocantins, Brazil. Revista Brasileira de Botânica 30: 375-385.

Felfili, J.M.; Rezende, A.V.; Silva Jr., M.C. \& Silva, M.A. 2000. Changes in the floristic composition of cerrado sensu stricto in Brazil over a nine-year period. Journal of Tropical Ecology 16: 579-590.

Gomes, L.; Lenza, E.; Maracahipes, L.; Marimon, B.S. \& Oliveira, E.A. 2011. Comparações florísticas e estruturais entre duas comunidades lenhosas de cerrado típico e cerrado rupestre, Mato Grosso, Brasil. Acta Botanica Brasílica 25: 865-875.

Gomes, L.; Maracahipes, L.; Marimon, B.S.; Reis, S.M.; Elias, F.; Maracahipes-Santos, L.; Marimon-Junior, B. \& Lenza, E. 2014. Post-fire recovery of savana vegetation from rocky outcrops. Flora 209: 201-208.

Guimarães, J.C.C.; Van Den Berg, E.; Castro, G.C.; Machado, E.L.M. \& Oliveira-Filho, A.T. 2008. Dinâmica do componente arbustivo-arbóreo de uma floresta de galeria aluvial no planalto de Poços de Caldas, MG, Brasil. Revista Brasileira de Botânica 31: 621-632.

Henriques, R.P.B. \& Hay, J.D. 2002. Patterns and dynamics of plant populations. In: Oliveira, P.S. \& Marquis, R.J. (eds.). Cerrados of Brazil: ecology and natural history a Neotropical Savanna. Columbia University Press, New York. Pp.140-158.

Hollander, M. \& Wolfe, D.A. 1973. Nonparametric Statistical Methods. John Wiley \& Sons, New York. 816p.

Kent, M. \& Coker, P. 1992. Vegetation description and analysis; a practical approach. Bealhaven Press, London. 363p.

Klink, C.A. \& Machado, R.B. 2005. Conservation of the brazilian Cerrado. Conservation Biology 19: 707-713.

Korning, J. \& Balslev, H. 1994. Growth and mortality of trees in amazonian tropical rain forest in Ecuador. Journal of Vegetation Science 5: 77-86.

Lewis, S.L.; Phillips, O.L.; Sheil, D.; Vinceti, B.; Baker, T.R.; Brown, S.; Graham, A.W.; Higuchi, N.; Hilbert, D.W.; Laurance, W.F.; Lejoly, J.; Malhi, Y.; Monteagudo, A.; Vargas, P.N.; Sonké, B.; Supardi, N.; Terborgh, J.W. \& Martínez, R.V. 2004. Tropical forest tree mortality, recruitment and turnover rates: calculation, interpretation and comparison when census intervals vary. Journal of Ecology 92: 929-944.

Libano, A.M. \& Felfili, J.M. 2006. Mudanças temporais na composição florística e na diversidade de um cerrado sensu stricto do Brasil Central em um 
período de 18 anos (1985-2003). Acta Botanica Brasilica 20: 927-936.

Lieberman, D.; Lieberman, M.; Peralta, R. \& Hartshorn, G.S. 1985. Mortality patterns and stand turnover rates in a Wet Tropical forest in a Costa Rica. Journal of Ecology 73: 915-924.

Lima, E.S.; Lima, H.S. \& Ratter, J.A. 2009. Mudanças pós-fogo na estrutura e composição da vegetação lenhosa em um cerrado mesotrófico no período de cinco anos (1997-2002) em Nova Xavantina-MT. Cerne 15: 468-480.

Lopes, S.F; Vale, V.S. \& Schiavini, I. 2009. Efeito de queimadas sobre a estrutura e composição da comunidade vegetal lenhosa do cerrado sentido restrito em Caldas Novas, GO. Revista Árvore 33: 695-704.

Marimon-Junior, B.H. \& Haridasan, M. 2005. Comparação da vegetação arbórea e características edáficas de um cerradão e um cerrado sensu stricto em áreas adjacentes sobre solo distrófico no leste de Mato Grosso, Brasil. Acta Botanica Brasilica 19: 913-926.

McCune, B. \& Grace, J.B. 2002. Analysis of ecological communities. MjM Software Design, Gleneden Beach. 300p.

Mews, H.A.; Marimon, B.S.; Maracahipes, L.; Franczak, D.D. \& Marimon-Junior, B.H. 2011. Dinâmica da comunidade lenhosa de um Cerrado Típico na região Nordeste do Estado de Mato Grosso, Brasil. Biota Neotropica 11: 73-82.

Miranda, H.S. \& Sato, M.N. 2005. Efeito do fogo na vegetação lenhosa do Cerrado. In: Scariot, A.; Sousa-Silva, J.C. \& Felfili, J.M. (eds.). Cerrado: ecologia, biodiversidade e conservação, ministério do meio ambiente. Departamento de Ecologia Universidade de Brasília, Brasília. Pp. 95-103.

Miranda H.S.; Neto W.N. \& Neves B.M.C. 2010. Caracterização das queimadas de Cerrado. In: Miranda, H.S (ed.). Efeitos do regime do fogo sobre a estrutura de comunidades de cerrado: Resultados do Projeto Fogo. IBAMA, Brasília. Pp. 23-33.

Oliveira-Filho, A.T. 1994. Estudos ecológicos da vegetação como subsídios para programas de revegetação com espécies nativas: uma proposta metodológica. Cerne 1: 64-72.

Oliveira-Filho, A.T.; Mello, J.M. \& Scolforo, J.R.S. 1997. Effects of past disturbance and edges on tree community structure and dynamics within a fragment of tropical semideciduous forest in southeastern Brazil over a five-year period (19871992). Plant Ecology 131: 45-66.

Peel, M.C.; Finlayson, B.L. \& McMahon, T.A. 2007. Updated world map of the Koppen-Geiger climate classification. Hydrology and Earth System Sciences 11: 1633-1644.

Philip, M.S. 1994. Measuring trees and forests. University Press, Cambridge. 310p.

Pinto, J.R.R.; Lenza, E. \& Pinto, A.S. 2009. Composição florística e estrutura da vegetação arbustivo-arbórea em um cerrado rupestre, Cocalzinho de Goiás, Goiás. Revista Brasileira de Botânica 32: 23-32.

Pivello, V.R. 2011. The use of fire in the cerrado and Amazonian rainforests of Brazil: Past and present. Fire Ecology 7: 24-39.

R Development Core Team. 2009. R: a language and environment for statistical computing. R Foundation for Statistical Computing, Vienna. 3501p.

Reatto, A.; Correia, J.R.; Spera, S.T. \& Martins, E.S. 2008. Solos do Bioma Cerrado: aspectos pedológicos. In: Sano, S.M.; Almeida, S.P. \& Ribeiro, J.P. (eds.). Cerrado: ecologia e flora. Embrapa, Planaltina. Pp. 107-134.

Ribeiro, J.F. \& Walter, B.M.T. 2008. As principais fitofisionomias do bioma Cerrado. In: Sano, S.M.; Almeida, S.P. \& Ribeiro, J.P. (eds.). Cerrado: ecologia e flora. Embrapa, Planaltina. Pp.151-199.

Ribeiro, M.N.; Sanchez, M.; Pedroni, F. \& Peixoto, K.S. 2012. Fogo e dinâmica da comunidade lenhosa em cerrado sentido restrito, Barra do Garças, Mato Grosso. Acta Botanica Brasilica 26: 203-217.

Silva, F.A.M.; Assad, E.D. \& Evangelista, B.A. 2008. Caracterização Climática do Bioma Cerrado. In: Sano, S.M.; Almeida, S.P. \& Ribeiro, J.P. (eds.). Cerrado: ecologia e flora. Embrapa, Planaltina. Pp. 69-88.

Sheil, D.; Burslem, D.F.R.P. \& Alder, D. 1995. The interpretation and misinterpretation of mortality rate measures. Journal of Ecology 83: 331-333.

Sheil, D.; Jennings, S. \& Savill, P. 2000. Long-term permanent plot observations of vegetation dynamics in Budongo, a Ugandan rain forest. Journal of Tropical Ecology 16: 765-800.

Spiegel, M.P. 1976. Estatística. McGraw-Hill, São Paulo. 580p.

The International Plant Names Index. 2012. Disponível em: <http://www.ipni.org/>. Access on 20 August 2015.

Zar, J.H. 2010. Biostatistical Analisys. Pearson, Upper Saddle River. 944p. 